\title{
The Causative Factor of Semantic Error in the Students' Assignment Papers at Widya Mandala Madiun Catholic University-Indonesia
}

\author{
Pramudita Septiani, Sarwiji Suwandi, Budhi Setiawan
}

Postgraduate, Sebelas Maret University, Ir. Sutami street, No. 36 A Kentingan Surakarta, Central Java, Indonesia Corresponding Author Email: pramudity a.09@ gmail.com

\begin{abstract}
This study aims to explain and describe the causative factors of language errors in semantic on the students' assignment papers. The subjects of this study were students who had taken MKU-BI (Indonesian General Course) courses at Widya Mandala Madiun Catholic University, who came from various disciplines. This research uses descriptive qualitative research, and observation and field note techniques as data collection techniques. The results of the data are documents (in the form of students' assignment papers) and students' interviews. Data analysis techniques used in this study is sharing methods or distribution methods with advanced techniques in the form of extension (expansion) techniques and changing forms. The conclusions of the study are the causative factors of language errors at the syntactic level caused by (1) Affected by the language that was mastered first, (2) Language users' lack of understanding over the use of the language, (3) Language teaching that is less precise or imperfect. Keywords-Causative Factor, Semantic Error, WIMA Madiun
\end{abstract}

\section{INTRODUCTION}

The important role of MKU-BI (Indonesian General Course) here is strongly felt; MKU-BI is trying to develop the ability of students' writing with expectation that they can use the correct Indonesian rules. Therefore, the quality of scientific work is created (fulfilling the requirements: objective, cohesion and coherence, effective, and efficient). On the other hand, in fact there are still many mistakes made by students in writing papers. Whereas, making papers like making other scientific works must meet the systematic and logical elements. Systematic can be seen from the structure or continuous sequence of chapters, while logical is seen from each word choices arranged together to form a cohesive and coherent sentence.

Freyhofer (2008: 47) explained that learners do not really like paper writing skills lesson. They feel bored when writing a paper. Even though the ability of writing a paper is a benchmark for students' success in writing other scientific works such as: journal articles, researches, theses, and dissertations, because a paper is the first scientific assignment given by a lecturer to a student before going to another scientific work. Thus it has become a necessity if this ability needs to be considered by all parties.

Zaenal and Tasae (2000: 2) explained that the paper presents an issue whose discussion is based on empiricalobjective data in the field. Paper prepared by a person or group that discusses a subject that is the result of research is in the field of education and culture. Papers are usually a form of lecture assignment or requirement for discussion and seminar (Bungin, 2014: 226).

This research is different from the research conducted by Sutarsih (2017: 89), Parwati (2015: 37) and Masfufah (2018: 251) who focus more on phonological problems. Phonology is the field of linguistics that studies, analyzes, and discusses the sequence of sounds of language (Chaer, 2008: 102). Otherwise research conducted by Nurhayatin, et. al (2018: 102) and Dewi, et.al (2014) who found errors in students' scientific work, especially in the field of sentences that included structure, alignment, spelling, diction, and logic is also different. This research is almost the same as research conducted by Kurniawati, (2014: 133) which highlights the problem of micro linguistics, especially in semantic. However, in different views if Kurniawati's research highlights the problem of reduplication noun in the semantic field, this research highlights the causative factors that cause errors in the semantic field.

Semantic position in linguistics is as a component contained in linguistics, as well as components of sound and grammar (Palmer, 1981: 5). Semantics is generally defined as the study of meaning (Lyons, 1971: 1). Mulyono (1964: 1) explained more detail that semantics is a branch of linguistics whose task is to study the word, how it starts, how it develops, and what causes changes in 
meaning in the language history. Semantics in a slight intelligence is distinguished on two points, namely (1) reference theory (denotation of extension) and (2) theory of meaning (connotation, intention) (Suwandi, 2011: 4).

Language errors according to Setyawati(2017: 13) mean the use of language both verbally and writing that deviates from the determinants of communication or deviates from social norms and deviates from the rules of Indonesian grammar. Meanwhile, Pranowo (1996: 58) explained the analysis of language errors that have an understanding as a theory used to analyse the language between language learners (interlanguage). Corder (1981: 274) explained three reasons for the importance of carrying out error analysis. First, the results of error analysis play an important role for learners because they can know the extent to which learning objectives are achieved and the things that must be done to improve the quality of learning outcomes. Second, by the results of error analysis, teachers can find out how learners learn or obtain language and the strategies or processes used by learners in languages learning. Third, as the most important aspect, error analys is needs to be done because it can help learners learn and understand language through mistakes and learn them. This study uses the linguistic taxonomy presented by Dulay, Burt \&Krashen (1982: 163). In this taxonomy it discusses micro linguistics (phonology, syntax, morphology, and semantics) as well as macro linguistics (discourse). However, this research focuses more on the semantic field.

It is important to analyze the errors on the semantic field in students' scientific work, because at this semantic field the meaning of each word, sentence or discourse can be understood completely by the reader. Like the research conducted by Agu, Et. Al (2018: 948-954) who explained that there is a connection between linguistic systems in every sermon study in Nigeria, where semantics allow preachers to adopt simple words and sentences which are expected by adherents to understand the meaning of words and sentences and absorb them into positive teachings. This research proves that the importance of semantics in the transfer of meaning between speakers and listeners or between writers and readers.

This research was conducted at Widya Mandala Madiun Catholic University or commonly called WIMA. The basis for choosing WIMA is because the researchers still found many language errors at semantic in the students' assignment papers and this happened probably due to the students' background who obtained their mother tongue, especially each student's local language is not Indonesian. Based on observations, Widya Mandala
Madiun Catholic University students are from various ethnic groups in Indonesia, so Indonesian was not the first language that they mastered. Furthermore, it will be known whether there is an error factor after being reviewed in the discussion. The discovery of many language errors at the semantic field in the Widya Mandala Madiun Catholic University illustrates that the ability to write scientific papers in Widya Mandala Madiun Catholic University students is not entirely good.

The problem statement in this research is what the causative factors of language errors at the semantic field in the students' assignment papers at Widya Mandala Madiun Catholic University are. The purpose of this study is to explain and describe the causative factors of language errors at the semantic field in the students' assignment papers at Widya Mandala Madiun Catholic University.

\section{METHOD}

This research uses descriptive qualitative research. Qualitative research is a research conducted by assessment methods or research methods on a problem that is not intended or designed using statistical procedures (Subroto, 1992: 5). The method used in this research is descriptive method because researchers want to illustrated or describe the result of the data. This means that the data obtained is explained using words, or sentences and not in the form of numbers or counts. This is in accordance with the opinion of Moleong (2012: 12) which says that the data collected is in the form of words, pictures and not numbers. The data source of this research is students' papers and informants. The student papers and informants were randomly drawn from various study programs and faculties of students who had received MKU-BI lectures.

The data collection technique in this research is observation methods continued with field note techniques. The observation methods is done to observe the use of the language. The term observation here is not only related to the use of language verbally, but also the use of written language (Mahsun, 2005: 92). Verbal data obtained from the interviews and written data obtained from the students' scientific work. The first thing that the researchers do is look at all the results of student papers, and then record all types of errors. After knowing the types of errors in the syntax field then it will be interviewed to the concerned students, to find out the causative factors of the error.

The analytical method used is distribution method. The distribution method or the sharing method is an analytical method where the determinant is inside and 
being the part of the researched language (Sudaryanto, 1993: 15).

\section{RESULT AND DISCUSSION}

It is important to analyze language errors at the semantic level in students' scientific work, because at this semantic level the meaning of each word, sentence, or discourse can be fully understood by the reader. Research conducted by Rahmiati (2014) found internal factors that caused language errors in students' scientific work as follow: (1) laziness; (2) have no mood; (3) lack of understanding; and (4) have no ideas. Another case described by Setyawati (2017: 15), factors that cause language errors generally occur due to thestudents' scientific work are as follow: (1) Affected by the language that was mastered first, (2) Language users' lack of understanding over the use of the language, (3) Language teaching that is less precise or imperfect. Meanwhile, Jain (1985: 71); Fisiak (1985: 190) stated the factors as follows: (1) learning strategies, (2) teaching techniques, (3) second language folklore, (4) bilingualis m age, (5) students' sociolinguistic situation. The results of this study will be presented as follows:

\section{Affected By The Language That Was Mastered First}

According to Setyowati (2017: 15) this type of error means that a language error caused by interference between the mother tongue or first language (B1) against the second language (B2) that is being studied by the learner (student). In other words, the source of the error lies in the difference of the linguistic system B1 and the linguistic system B2. Indonesia is a rich country, there are thousands of islands, tribes, races, religions and languages. Indonesian children are mostly taught by parents, the first language is the language of their own regions of residence. Thusthe B1 of Indonesian children are Regional Languages. Then, for the Indonesian language will usually begin to be obtained at the time of association outside the home or at school. This often causes confusion that makes mixing language.

Widya Mandala Madiun Catholic University students come from various tribes, islands and races in Indonesia. Of course, their regional languages are also different. This study also found errors caused by the use of local languages.

Sample of the data:

(1) Tetapi, masih banyak orang yang belum memahami kaidah-kaidah dari Bahasa Indonesia itu sendiri ...
(2) Di Indonesia sendiri memang sudah banyak bank yang menggunakan akutansi syariah meski tak sebanyak bank konvensional..

The sentences in extracts 1,2 are sentences that are affected by local languages, especially Javanese. It can be seen from the sentence structure. The influence of Javanese is very strong in the formation of Indonesian sentences. Example sentences in Javanese:

- "kowe ki pancen ayu dewe" (You are the most beautiful woman)

- "Omahe Deri apik dewe neng desone" (Deri's house is the best in his village).

The word "dewe" (itself) is always used in Javanese as anemphasising. In Indonesiansentenceformation is often influenced by the Javanese language, especially the use of the word "dewe". The authors of the papers in this case are also students from Java with Javanese ethnicity. The word deweshould not appear in extracts 1,2 because it will overwhelm the word and make the sentence ineffective. Correction for sentence $(1,2)$ is:

- Tetapi, masih banyak orang yang belum memahami kaidah-kaidah dari Bahasa Indonesia...

- Di Indonesia memang sudah banyak bank yang menggunakan akutansi syariah meski tak sebanyak bank konvensional..

consider the next example:

(3) Bimbingan dan konseling adalah sebuah proses interaksi antara konselor dengan konseli baik secara langsung maupun tidak langsung dalam rangka untuk membantu konseli agar dapat mengembangkan potensi dirinya ataupun memecahkan permasalahan yang di alaminnya....

The word alamin is a non-standard word. The basic word is not alamin but alami which explains (things that have already happened). The word alamin is appeared because it was influenced by local languages, namely Batavia and Sundanese. Many of us often listen to people from the Bataviause this accent, for example in the discourse "yang guealamin", the word menjalankan becomes njalanin, etc. The Batavia language itself is divided into 3 main sub-dialects, namely: Betawi Kota, Betawi Udik, and Betawi Ora. The author above is also a person who comes from the Bogor. The author's B1 is Batavia Language, because his environment is also the environment of the Batavia people. Correction for sentence (4) is: 
Bimbingan dan konseling adalah sebuah proses interaksi antara konselor dengan konseli baik secara langsung maupun tidak langsung dalam rangka untuk membantu konseli agar dapat mengembangkan potensi dirinya ataupun memecahkan permasalahan yang di alaminya....

\section{Language Users' Lack Of Understanding Over The Use Of The Language}

Errors that reflect the general characteristics of the language rules are learned, ror example: generalization errors, imperfect application of language rules, and failure to learn the conditions of applying language rules. Those errors are often referred to as intralingua errors (Setyowati, 2017: 15).

Sample of the data:

(4) Di Indonesia wacana mengenai CSR mulai mengemuka pada tahun 2001, namun sebelum wacana ini mengemuka telah banyak perusahaan yang menjalankan CSR dan sangat sedikit sekali yang mengungkapkannya dalam sebuah laporan..

(5) Kiranya tidak berlebihan jika dikatakan bahwa satuan pengajaran (disain) instruksional, perencanaan pengajaran) ....

(6) Sebagai hewan yang berdarah dingin, amfibi tidak aktif dalam kondisi dingin...

In the sentence (5) there are two adverbs at once to explain the adjective, hence there is an excessive superlative form. It should be enough to choose one of the adverbs to explain the adjective. In sentence (6) there is an error in writing the word "disain". Referring to Alwi (2014: 11) in a word choice it must also meet the truth requirements. The correct word is a word that is spoken or written according to the correct form (both basic form and invented form). In sentence (7) refered to Alwi (2014: 11 ) in a word choice it must also meet the requirements of the word prevalence. Common words are words that are commonly used to express certain ideas. The word tidak aktif selected in the sentence above makes the sentence is incomprehensible. It would be better if the word tidak aktif replaced with the word hibernasi. The word hibernasi is more commonly used in scientific terms. Correction of the sentence above is as follows

- 5a. Di Indonesia wacana mengenai CSR mulai mengemuka pada tahun 2001, namun sebelum wacana ini mengemuka telah banyak perusahaan yang menjalankan CSR dan sangat sedikit yang mengungkapkannya dalam sebuah laporan.

- 5b. Di Indonesia wacana mengenai CSR mulai mengemuka pada tahun 2001, namun sebelum wacana ini mengemuka telah banyak perusahaan yang menjalankan CSR dan sedikit sekali yang mengungkapkannya dalam sebuah laporan

- Kiranya tidak berlebihan jika dikatakan bahwa satuan pengajaran (desain) instruksional, perencanaan pengajaran) ....

- Sebagai hewan yang berdarah dingin, amfibi hibernasi dalam kondisi dingin.

\section{Language Teaching That Is Less Precise Or Imperfect}

It is related to the material being taught or trained and how to implement the teaching. Teaching material concerns to the source, the selection, the arrangement, the ordering, and the emphasis. The way of teaching involves the problem of choosing the presentation technique, steps and sequence of presentation, intensity and continuity of teaching, and assistive devices in teaching. Based on the results of the interview with a MKU-BI lectures student, it was considered to be imperfect due to various causes:

1. Lecturers who are often absent during lectures.

"iya bu, dosen Bahasa Indonesianya sering gak datang, mungkin karena dosen luar prodi jadi sering lupa..." ("Yes ma'am, the Indonesian Language lecturer often does not come, maybe because lecturers outside the study program often forget ...")

2. Lecturers lack of creativity in giving lectures, so students often feel bored. This makes what the lecturers taught cannot be kept long by students in their memory.

3. Students are confused if there are some errors in making papers, in this case the semantic errors, because usually lecturers only give assignments and submit into the lecturers without further review.

4. The factor of lazy students, in learning and reading books, also causes many errors.

\section{CONCLUSION}

Causative Factors of Language Errors in Students' Papers at Widya Mandala Madiun Catholic University at the syntactic level include: (1) Affected by the language that was mastered first, (2) Language users' lack of understanding over the use of the language, (3) Language teaching that is less precise or imperfect. Solutions to overcome these problems include: (1) Lecturers must be more innovative in lectures and always review the results of student assignments, and (2) the participation of all parties in efforts to improve the ability to write papers is needed, especially in the semantic field, such asthe campus organizesa writing competitions paper. 


\section{REFERENCES}

[1] Freyhofer, H. (2008). I Hate History Papers. Journal on Writing Across the Curriculum, 11(2), 11-17. https://wac.colostate.edu/docs/journal/vol11/freyhofer.pdf

[2] Zaenal, A. E. \& Tasae, A. S. (2000). Cermat Berbahasa Indonesia. Jakarta: Akademika

[3] Bungin, B. (2014). Penelitain Kualitatif. Jakarta: Kencana Prenada Media

[4] Sutarsih. (2017). Penanda Fonologi Bahasa Jawa Dalam Tuturan Masyarakat di Gang Baru Semarang. Aksara, (ISSN: 0854-3283(P) | ISSN: 2580-0353(O)), 29(1), 90102 DOI: http://dx.doi.org/10.29255/aksara.v29i1.103.89102

[5] Parwati, S. A. P. E. (2015). Realisasi Fonetis Konsonan Getar Alveolar Bahasa Indonesia Pada Laki-Laki dan Perempuan Dewasa. Aksara, , (ISSN: 0854-3283(P) | ISSN: 2580-0353(O)), 27(1), 37-47. DOI: http://dx.doi.org/10.29255/aksara.v29i1.103.89-102

[6] Masfufah, N. (2018). Sistem Fonologi Bahasa Benuq di Kabupaten Kutai Barat- Kalimantan Timur. Aksara, (ISSN: 0854-3283(P) | ISSN: 2580-0353(O)), 30(2), 251265.

DOI:http://dx.doi.org/10.29255/aksara.v30i2.216.251-265

[7] Chaer, A. (2008). Morfologi Bahasa Indonesia (Pendekatan Proses). Jakarta: PT. Rineka Cipta.

[8] Nurhayatin, T. Et, al. (2018). Analisis Keefektifan Penggunaan Kalimat Dalam Karya Ilmiah Mahasiswa Pendidikan Guru Sekolah Dasar. JPSD, (ISSN: 25409093(P) | ISSN: 2503-0558(O)), 4(1), 102-114. DOI: http://dx.doi.org/10.30870/jpsd.v4i1.2911

[9] Dewi, Ni. Km. A.Y. \& Et, al. (2014) Analsis Kesalahan Bahasa Indonesia Pada Esai Mahasiswa Jurusan Pendidikan Bahasa dan Sastra Indonesia: Sebuah Kajian Ejaan, Diksi, dan Struktur. Jurnal Pendidikan Bahasa dan Sastra Indonesia (Undiksha), 2(1), 2-10. https://ejournal.undiksha.ac.id/index.php/JJPBS/article/vie $\mathrm{w} / 2592 / 2204$

[10] Kurniawati, W. (2014). Reduplikasi Nomina Dalam Bahasa Indonesia: Kajian Sintaksis dan Semantik. Aksara, (ISSN: 0854-3283(P) | ISSN: 2580-0353(O)), 26(2), 133143. DOI: http://dx.doi.org/10.29255/aksara.v26i2.155.133-143

[11] Palmer, F. R. (1981). Semantics. Sydney: Cambridge University Press.

[12] Lyons, John. (1977). Semantics. Volume I. Melbourne: Cambridge University Press.

[13] Mulyono, S. (1964). Semantik: Ilmu Makna. Jakarta: Djambatan.

Suwandi, S. (2011). Semantika Pengantar Kajian Makna. Yogy akarta: Media Perkasa.

[14] Setyowati, N. (2017). Analisis Kesalahan Berbahasa Indonesia: Teori dan Praktik. Surakarta: Yuma Pustaka.

[15] Pranowo. (1996). Analisis Pengajaran Bahasa. Yogy akarta: Gajah Mada University Press.

[16] Corder, S. P. (1981). Error Analysis and Interlanguage. Oxford: University Press.
[17] Dulay, H., Burt, M., \& Krashen, S. (1982). Language Two. Oxford: Oxford University Press.

[18] Agu. I. E. Et, al. (2018). A Linguistic Analysis of Friday Sermons of three Mosques in Yola Adamawa State Nigeria. International Journal of English Literature and Social Sciences (IJELS),(ISSN: 2425-7640), 3(6), 948954. http://dx.doi.org/10.22161/ijels.3.6.4

[19] Subroto. (1992). Penelitian Kwalitatif. Jakarta: Raja Grafindo Persada.

[20] Moleong, L. J. (2007). Metodologi Penelitian Kualitatif. Bandung: PT. Remaja Rosdakarya, 2007.

[21] Mahsun, M. S. (2005). Metode Penelitian Bahasa: Tahapan Strategi, Metode, dan Tekniknya. Jakarta: Rajawali Pers.

[22] Sudaryanto. (1993). Metode dan Aneka Teknik Analisis Bahasa (Pengantar Penelitian Wahana Kebudayaan Secara Linguistik). Yogy akarta: Duta Wacana Press.

[23] Rahmiati. (2014) Analisis Kendala Internal Mahasiswa Dalam Menulis Karya Ilmiah. Aldaulah, 3 (2), 254-268. DOI: https://doi.org/10.24252/ad.v4i2.1486

[24] Jain, M. P. (1985). Error Analysis: Source, Cause and Significance. London: Longman

[25] Fisiak, J. [Eds]. (1985). Contrastive Linguistics and The Language Theacher. Oxford: Pergamon Press.

[26] Alwi, H. (2014). Tata Bahasa Baku Bahasa Indonesia. Jakarta: Balai Pustaka. 